\title{
Biotin deficiency and fatty liver and kidney syndrome in chicks given purified diets containing different fat and protein levels
}

\author{
By C. C. WHITEHEAD, D. W. BANNISTER, A. J. EVANS, \\ W. G. SILLER AND P. A. L. WIGHT \\ Agricultural Research Council's Poultry Research Centre, \\ West Mains Road, Edinburgh EH9 3 FS \\ (Received 21 April 1975 - Accepted 8 fuly 1975)
}

\begin{abstract}
1. The occurrence of biotin deficiency and fatty liver and kidney syndrome (FLKS) in chicks was studied using a $2 \times 2 \times 2 \times 2$ factorial-design experiment in which the variables were dietary biotin, fat and protein, and starvation.

2. The severity of biotin deficiency, using growth retardation and severity of dermal lesions as criteria, was least when the low-biotin diet also contained low levels of fat and protein. Addition of fat or protein increased the severity of the deficiency. Tissue fatty acid composition was affected by biotin deficiency only in those birds given the low-protein, low-fat diet. The main change was an increase in the ratio, $16:$ : fatty acids: 18 : o fatty acids. Plasma glucose and free fatty acid levels in non-fasted birds were unaffected by the dietary variables.

3. Mortality from FLKS with the diet containing low biotin, fat and protein levels was $52 \%$ at $\mathbf{2 8} \mathrm{d}$, but was reduced or eliminated when the dietary level of any of these ingredients was increased.

4. Starvation considerably increased the incidence of FLKS in the period immediately after fasting, and also affected plasma glucose and free fatty acid concentrations. Liver fatty acid composition indicated an increase in the proportion of $18: 0$ at the expense of $16: 1$ and I8: 1 , irrespective of diet, except when the bird developed FLKS, when I6: I and I8: 1 concentrations increased in proportion, at the expense of $18: 0$.

5. The relationship between biotin deficiency and FLKS, and a possible mechanism for the induction of FLKS by starvation are discussed.
\end{abstract}

It has been found recently that fatty liver and kidney syndrome (FLKS), a fatal condition in chicks, is a metabolic disorder that can be influenced by several nutritional factors. The incidence of FLKS can be reduced by increasing the amounts of protein (Whitehead \& Blair, I974a) or fat (Blair, Whitehead \& Teague, I975; Whitehead, Blair, Bannister \& Evans, 1975) in a practical broiler diet which caused high mortality, and can be virtually eliminated by supplementing the diet with biotin (Payne, Gilchrist, Pearson \& Hemsley, 1974; Whitehead \& Blair, 1974 $b$; Whitehead, Blair, Bannister, Evans \& Jones, 1975).

The characteristic changes associated with FLKS are fatty infiltrations of liver, kidney, heart and other organs (Wight $\&$ Siller, 1975) reduced plasma glucose concentrations, increased plasma free fatty acids (FFA) and sometimes also increased plasma triglyceride levels (Bannister, Evans \& Whitehead, I975 $a$; Evans, Bannister $\&$ Whitehead, 1975). Changes are found also in liver and kidney fatty acid composition: there is a large increase in the proportion of $16: \mathrm{I}$ fatty acids and a large decrease in that of $18: 0$ fatty acids, as well as a smaller increase and decrease in the proportions of $\mathrm{I} 8: \mathrm{x}$ and $\mathrm{I} 6: 0$ respectively (Whitehead, $\mathrm{I975}$ ).

Although the syndrome is associated with diets of low available biotin content, 
birds dying from it need not show any of the recognized signs of biotin deficiency (Whitehead, Blair, Bannister, Evans \& Jones, r975). The usual signs of biotin deficiency are dermal lesions of the feet, eyelids and angles of the beak. Other signs are poor growth and feathering, abnormalities of the shape of the beak and sometimes perosis (Scott, Nesheim \& Young, 1969). Changes have also been reported in tissue fatty acid composition, mainly an increase in the ratio, I6: I fatty acids: $18: 0$ fatty acids (Roland 8 Edwards, I97I). The results of a recent study of biotin deficiency, using diets containing high levels of protein and fat, confirmed most of these findings, except those for fatty acid composition, and did not suggest any changes characteristic of FLKS (Whitehead, Bannister, Wight \& Weiser, 1974).

The hypoglycaemia that is an important feature of FLKS is thought to be due in part to a failure of hepatic gluconeogenesis. Biotin is a cofactor for pyruvate carboxylase (EC 6.4 I I I pyruvate : carbon-dioxide ligase (ADP)), a key enzyme in gluconeogenesis, and addition of biotin has been found to restore hepatic gluconeogenesis both in vitro and in vivo in FLKS (Bannister, 1975; Bannister et al. 1975a). Although this mechanism explains why biotin prevents FLKS, it does not suggest how biotin deficiency as such might initiate the syndrome. However, starvation has been found to result in an increase in mortality from FLKS in the period immediately after fasting (Hemsley, 1973; Whitehead, Blair, Bannister \& Evans, 1975) and may trigger the syndrome by placing a sudden demand on the bird's gluconeogenic system which it is unable to meet.

The object of the present study was to determine the relationship between biotin deficiency and FLKS in chicks given diets containing different fat and protein levels and to study the role of starvation in inducing the syndrome. All the main factors known to be involved in the two conditions were used as criteria.

\section{EXPERIMENTAL}

\section{Diets}

The compositions of the biotin-deficient diets (diets $1,3,5$ and 7 ) are given in Table I. Diets I and 3 had the same protein level ( $180 \mathrm{~g}$ crude protein $(\mathrm{CP}) / \mathrm{kg}$ ) but low and high fat levels (10 and $150 \mathrm{~g}$ maize oil $/ \mathrm{kg}$ respectively). Diets 5 and 7 contained $260 \mathrm{~g} \mathrm{CP}$, and 10 and I $50 \mathrm{~g}$ maize oil $/ \mathrm{kg}$ respectively. In the high-fat diets the maize oil was added at the expense of starch, and cellulose was added as an inert filler so that all diets were isoenergetic. The difference between the two protein levels was made up from a mixture of crystalline amino acids. Thus the main protein source and only source of biotin, Promine-R, an isolated soya-bean protein (Oppenheimer Casing Co., Edinburgh), was present in all diets in the same amount. The mean biotin content of the diets was found, by microbiological assay (Wright \& Skeggs, I944), to be $0.015 \mathrm{mg} / \mathrm{kg}$.

The control diets (diets $2,4,6$ and 8 ) were obtained by the addition of $0.5 \mathrm{mg}$ biotin/kg to diets $x, 3,5$ and 7 respectively. 
Table $\mathrm{x}$. Composition $(\mathrm{g} / \mathrm{kg})$ of biotin-deficient diets given to chicks

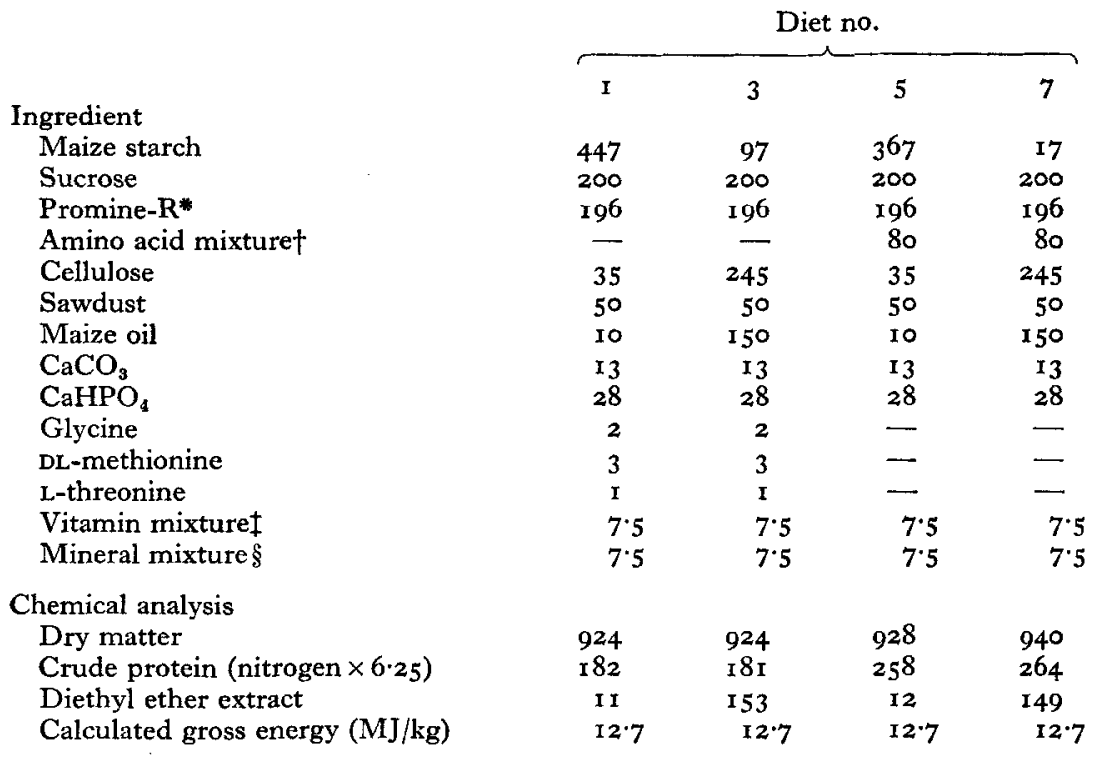

* Oppenheimer Casing Co., Edinburgh.

† Contained $(\mathrm{g} / \mathrm{kg})$ : L-lysine $8 \mathrm{r}$, L-arginine $8 \mathrm{r}$, L-aspartic acid 125 , L-threonine 47 , L-glutamic acid 235, L-proline 3I, L-glycine 3I, DL-methionine 47, L-valine 3I, L-leucine 94, L-phenylalanine 3I, L-tyrosine 3I, L-histidine 3I, L-isoleucine 62, L-alanine 3I, L-tryptophan 15.

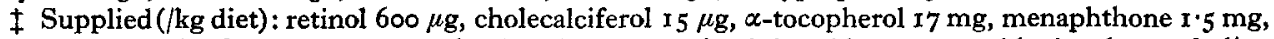
thiamin $4 \mathrm{mg}$, riboflavin $7 \mathrm{mg}$, pantothenic acid $20 \mathrm{mg}$, nicotinic acid $54 \mathrm{mg}$, pyridoxine $6 \mathrm{mg}$, choline chloride $2.5 \mathrm{~g}$, pteroylmonoglutamic acid $2 \mathrm{mg}$, cyanocobalamin $0.03 \mathrm{mg}$, myo-inositol $0.1 \mathrm{~g}$, $p$-aminobenzoic acid $2 \mathrm{mg}$.

\& Supplied (/kg diet): $\mathrm{K}_{2} \mathrm{CO}_{3} 5.2 \mathrm{~g}, \mathrm{NaCl}_{2} .7 \mathrm{~g}, \mathrm{CuSO}_{4} .5 \mathrm{H}_{2} \mathrm{O} 15 \mathrm{mg}, \mathrm{KIO}_{3} 0.6 \mathrm{mg}, \mathrm{FeSO}_{4} .7 \mathrm{H}_{2} \mathrm{O}$ $0.25 \mathrm{~g}, \mathrm{MgCO}_{3} \mathrm{I} \cdot 2 \mathrm{~g}, \mathrm{MnCO}_{3} 0.09 \mathrm{~g}, \mathrm{ZnO} 25 \mathrm{mg}, \mathrm{H}_{3} \mathrm{BO}_{3} 9 \mathrm{mg}, \mathrm{CoSO}_{4} .7 \mathrm{H}_{2} \mathrm{O} \mathrm{Img}, \mathrm{Na}_{2} \mathrm{MoO}_{4} \cdot 2 \mathrm{H}_{2} \mathrm{O}$ $2.5 \mathrm{mg}, \mathrm{Na}_{2} \mathrm{SeO}_{3} 0.3 \mathrm{mg}$.

\section{Procedure}

Expt I. Female Ross I broiler chicks (I d old) were weighed, wing-banded and allocated to eighteen compartments in a tier brooder, twelve birds/compartment. Diets 2-8 were each fed to birds in two compartments, but diet I was supplied to four compartments as a high mortality rate was expected. Food and water were freely available and the daily light cycle was $23 \mathrm{~h}$ light and $\mathrm{I} h$ darkness.

The birds were weighed weekly and all those that died were examined post mortem. At $28 \mathrm{~d}$ of age, ten birds/diet were assessed subjectively for severity of lesions of biotin deficiency and marked on a scale ranging from $\circ$ (no lesions) to 5 (very severe lesions). Blood samples $\left(5^{-10} \mathrm{ml}\right)$ were taken and these birds were then killed by decapitation. Samples of various tissues were taken for chemical and histological analysis. A further ten birds/diet were deprived of food for $18 \mathrm{~h}$ overnight. At the end of this period, samples were taken for analysis as described previously.

Expt 2. As a result of the high mortality from FLKS up to $28 \mathrm{~d}$ of age among birds given diet $\mathrm{I}$ in Expt I, a second experiment was done to determine mortality up to $5^{6} \mathrm{~d}$ of age. Fifteen $\mathrm{I}$-d-old, female Ross I broiler chicks were housed in a tier 
Table 2. Live weights and severity of dermal lesions at $28 d$ of age in chicks given biotin-deficient or biotin-supplemented diets with high or low protein and fat contents

\begin{tabular}{|c|c|c|c|c|c|c|c|}
\hline \multirow[b]{3}{*}{ Diet* } & \multirow{3}{*}{$\begin{array}{l}\text { No. of } \\
\text { chicks }\end{array}$} & \multirow{2}{*}{\multicolumn{2}{|c|}{ Live wt (g) }} & \multicolumn{4}{|c|}{ Severity of lesionst } \\
\hline & & & & \multirow[b]{2}{*}{ Feet } & \multirow{2}{*}{$\begin{array}{l}\text { Angles } \\
\text { of beak }\end{array}$} & \multirow[b]{2}{*}{ Eyelids } & \multirow{2}{*}{$\begin{array}{l}\text { Total } \\
\text { score }\end{array}$} \\
\hline & & Mean & SE & & & & \\
\hline \multicolumn{8}{|l|}{ Biotin-deficient } \\
\hline I (low-protein, low-fat) & 23 & 322 & $\mathrm{II}^{a}$ & $2 \cdot 0$ & $2 \cdot 4$ & 0.6 & $5 \cdot 0$ \\
\hline 3 (low-protein, high-fat) & 24 & 239 & $9^{b}$ & $3 \cdot 0$ & $3 \cdot 0$ & 0.8 & $6 \cdot 8$ \\
\hline 5 (high-protein, low-fat) & 23 & 286 & $8^{e}$ & 3.0 & $2 \cdot 1$ & 0.1 & $5 \cdot 2$ \\
\hline 7 (high-protein, high-fat) & 24 & 190 & $7^{d}$ & $3 \cdot 2$ & $3 \cdot 0$ & 0.9 & $7 \cdot 1$ \\
\hline \multicolumn{8}{|l|}{ Biotin-supplemented } \\
\hline 2 (low-protein, low-fat) & 24 & 446 & $15^{e}$ & o & 0 & $\circ$ & 0 \\
\hline 4 (low-protein, high-fat) & 24 & 431 & $\mathbf{I} \mathbf{2}^{e}$ & $\circ$ & 0 & $\circ$ & 0 \\
\hline 6 (high-protein, low-fat) & 24 & 494 & $\mathrm{I} 7^{f}$ & o & 0 & o & 0 \\
\hline 8 (high-protein, high-fat) & 24 & 428 & $12^{e}$ & $\circ$ & o & $\circ$ & $\circ$ \\
\hline
\end{tabular}

brooder and given unrestricted access to diet $\mathrm{I}$ up to $56 \mathrm{~d}$ of age. (There were no control birds in this experiment.) All birds that died were examined post mortem.

\section{Methods}

Tissues for histological examination were fixed in formol-saline ( $100 \mathrm{ml}$ formalin/1 physiological saline $(9 \mathrm{~g} \mathrm{NaCl} / 1)$ ) and, for the study of lipid distribution, frozen sections were stained with Sudan IV. Diagnosis of FLKS was made on the basis of fatty infiltration in liver, kidney and heart as described by Wight \& Siller (1975).

Tissue lipids were extracted by the method of Folch, Lees \& Sloane Stanley (1957) and fatty acid compositions were determined by the methods described by Whitehead (1975).

Glucose content was determined in plasma by an automated enzymic method (Morley, Dawson \& Marks, I968) and plasma FFA and triglyceride concentrations were estimated as described previously (Evans et al. 1975).

\section{RESULTS \\ Expt I}

Live weight. Values for live weight of chicks at $28 \mathrm{~d}$ of age are given in Table 2. There was no significant $(P>0.05)$ difference in weight between birds given the two low-protein, control diets (diets 2 and 4 ). Birds given the high-protein, low-fat, control diet (diet 6) were significantly $(P<0.05)$ heavier than those given the low-protein, control diets or the high-protein, high-fat diet (diet 8). Birds given the biotin-deficient diets (diets I, 3,5 or 7) had considerable growth reductions which varied depending on the fat or protein content of the diets. Birds given the lowprotein, low-fat diet (diet I) had the lowest growth reduction (I24 g). Addition of fat 
Table 3. Incidence of fatty liver and kidney syndrome (FLKS) at $28 d$ of age or after fasting for a further I $8 \mathrm{~h}$ among chicks given biotin-deficient diets with high or low protein and fat contents

\begin{tabular}{|c|c|c|c|c|c|c|}
\hline \multirow[b]{3}{*}{ Diet* } & \multirow{3}{*}{$\begin{array}{l}\text { Total } \\
\text { no. of } \\
\text { chicks }\end{array}$} & \multirow{3}{*}{$\begin{array}{c}\text { No. of } \\
\text { deaths up } \\
\text { to } 28 \mathrm{~d} \text { of } \\
\text { age }\end{array}$} & \multicolumn{4}{|c|}{$\begin{array}{l}\text { No. of chicks, among groups of ten examined/ } \\
\text { treatment, showing histological changes of FLKS }\end{array}$} \\
\hline & & & \multirow[t]{2}{*}{ At $28 \mathrm{~d}$ of age } & \multicolumn{3}{|c|}{ After $18 \mathrm{~h}$ fast } \\
\hline & & & & $\begin{array}{l}\text { No. of } \\
\text { deaths }\end{array}$ & $\begin{array}{l}\text { No. of survivors } \\
\text { showing lesions }\end{array}$ & Total \\
\hline I (low-protein, low-fat) & 48 & 25 & 3 & 6 & 4 & IO \\
\hline 3 (low-protein, high-fat) & 24 & $\circ$ & 0 & $\circ$ & $\mathbf{I}$ & I \\
\hline 5 (high-protein, low-fat) & 24 & $\mathbf{I}$ & 2 & $\circ$ & 3 & 3 \\
\hline 7 (high-protein, high-fat) & 24 & $\circ$ & 0 & 0 & $\circ$ & 0 \\
\hline
\end{tabular}

(diet 3 ) or protein (diet 5 ) further reduced growth, to similar extents $(c .200 \mathrm{~g}$ ), and addition of both dietary factors (diet 7$)$ reduced growth still further $\left(23^{8} \mathrm{~g}\right)$.

Lesions typical of biotin deficiency. Lesions of biotin deficiency observed on birds given diets I, 3,5 or 7 were similar. There was dermatitis around the angles of the beak and of the feet and in severe cases papillomas occurred. At about 3 weeks of age, dermatitis also developed on the eyelids and in severe cases birds became unable to open their eyes, although the reason for this was unclear since the birds were not photophobic and there were no obvious signs of secretions which might have caused the eyelids to stick together. Bathing the eyes in water or saline had little effect on the condition. 'Parrot' beak and indentations on the ventral surface of the upper beak were also observed, as was abnormal feathering. The severities of the lesions varied with the diet (Table 2). Lesions were least severe among birds given diet I and most severe on those given diet 7 . No signs of biotin deficiency were seen on birds given diets $2,4,6$ or 8 .

Lesions typical of FLKS. The incidence of FLKS is given in Table 3. Mortality up to $28 \mathrm{~d}$ was high (twenty-five of the forty-eight birds) among birds given diet $\mathrm{I}$. In addition, three of the ten apparently healthy birds examined at $28 \mathrm{~d}$ had fatty infiltration of tissues and changes in liver fatty acid composition typical of FLKS. One bird given diet 5 died from FLKS and two of the ten killed at $28 \mathrm{~d}$ showed mild histological signs of the syndrome. Birds with unrestricted access to diets 3 or 7 did not show any clinical signs or histological lesions of FLKS.

On withdrawal of food for $18 \mathrm{~h}$ at $28 \mathrm{~d}$ all birds previously given diet $\mathrm{I}$ developed the syndrome. Of the ten birds in the group, six had died and the remaining four were showing clinical signs and histological changes ranging in extent from severe to mild by the end of $\mathrm{I} 8 \mathrm{~h}$ period. No birds previously given diets 3,5 or 7 had died by the end of this period. However, in group 3 one bird showed mild histological changes and, in the group given diet 5, two birds showed mild lesions and another showed severe lesions of FLKS. 


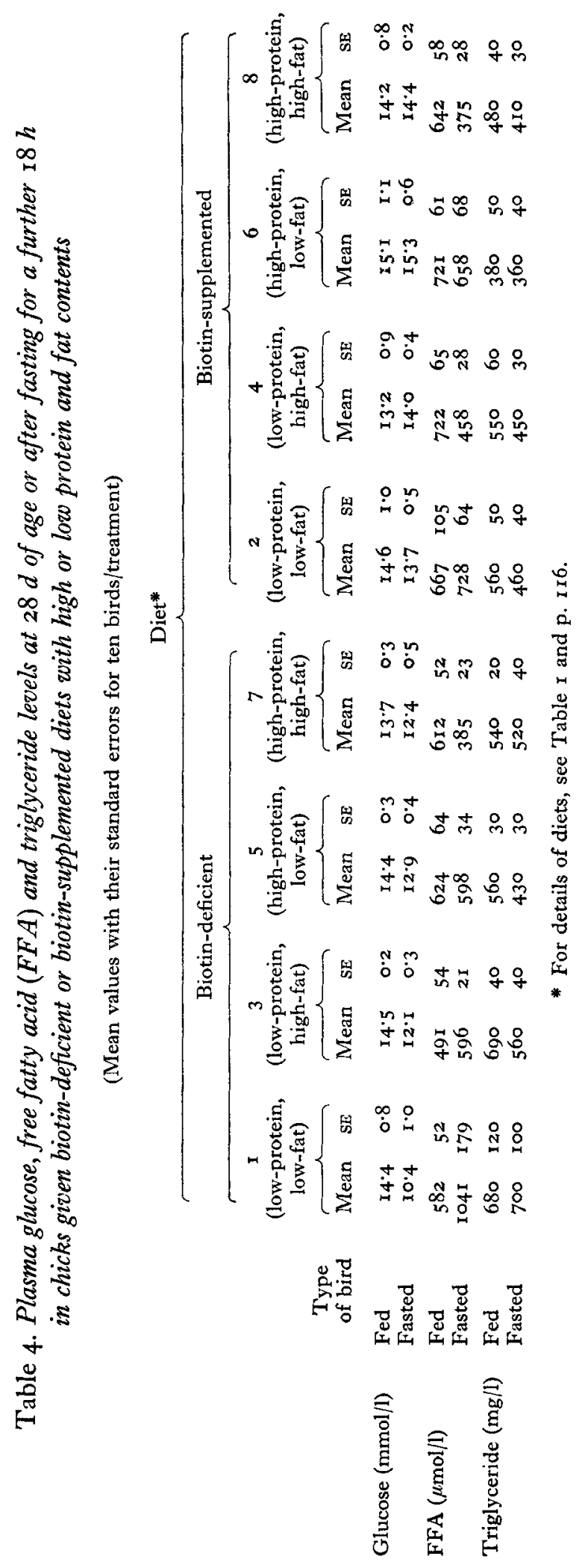


Table 5. Fatty acid composition of peritoneal adipose tissue at $28 d$ of age in chicks given biotin-deficient or biotin-supplemented diets with high or low protein and fat contents

(Mean values with their standard errors for five birds/treatment)

\begin{tabular}{|c|c|c|c|c|c|c|c|c|c|c|}
\hline \multirow[b]{3}{*}{ Diet* } & \multicolumn{10}{|c|}{ Component fatty acids $(\mathrm{mg} / \mathrm{g})$} \\
\hline & \multicolumn{2}{|c|}{$16: 0$} & \multicolumn{2}{|c|}{$16: 1$} & \multicolumn{2}{|c|}{ 18:0 } & \multicolumn{2}{|c|}{ 18: I } & \multicolumn{2}{|c|}{ I $8: 2$} \\
\hline & Mean & $\mathbf{S E}$ & Mean & SE & Mean & $\mathrm{SE}$ & Mean & SE & Mean & SE \\
\hline \multicolumn{11}{|l|}{ Biotin-deficient } \\
\hline I (low-protein, low-fat) & 305 & $8 \cdot 3$ & 170 & $13 \cdot 0$ & 39 & $4 \cdot I$ & 409 & $15 \cdot r$ & 77 & $5 \cdot 4$ \\
\hline 3 (low-protein, high-fat) & 126 & $5 \cdot I$ & 2 & $1 \cdot 3$ & 22 & $8 \cdot 3$ & 300 & IO. I & $55^{\circ}$ & 147 \\
\hline 5 (high-protein, low-fat) & 300 & $6 \cdot 9$ & 93 & $12 \cdot 9$ & 87 & 9.0 & 430 & I $2 \cdot I$ & $9 \mathrm{I}$ & $8 \cdot 7$ \\
\hline 7 (high-protein, high-fat) & 120 & $14 \cdot I$ & Io & $2 \cdot 1$ & 41 & $4^{*} \mathrm{I}$ & 287 & 9.2 & 539 & I $3 \cdot 6$ \\
\hline \multicolumn{11}{|l|}{ Biotin-supplemented } \\
\hline 2 (low-protein, low-fat) & 295 & $3 \cdot 2$ & 105 & $8 \cdot 0$ & 53 & $6 \cdot 1$ & $4^{8} 3$ & $7 \cdot 4$ & 64 & $4^{\prime 2}$ \\
\hline 4 (low-protein, high-fat) & 128 & 3.1 & 9 & $1 \cdot 6$ & 23 & 4.7 & 278 & 4.3 & 562 & II 2 \\
\hline 6 (high-protein, low-fat) & 3 II & $24 \cdot 6$ & 88 & $8 \cdot 0$ & 64 & $3 \cdot 5$ & 460 & 19.9 & 100 & 4.9 \\
\hline 8 (high-protein, high-fat) & I I 3 & $3 \cdot 3$ & 3 & 0.7 & 33 & $2 \cdot I$ & 285 & $3 \cdot 6$ & 566 & $4 \cdot 5$ \\
\hline
\end{tabular}

FLKS did not occur in any bird given the biotin-supplemented diets.

Plasma glucose, FFA and triglyceride levels. Values for plasma glucose levels of fed birds (killed at $28 \mathrm{~d}$ ) (Table 4$)$ indicated no statistically significant $(P>0.05)$ dietary effects. Fasted birds previously given diet $\mathrm{I}$ had hypoglycaemia typical of FLKS. Birds given the other low-protein diets (diets 2,3 and 4) also had significantly $(P<0.05)$ reduced plasma glucose levels as a result of fasting; birds given diet 2 had the greatest reduction. Plasma glucose levels of birds given the high-protein diets (diets 5,6,7 and 8) were not significantly affected by starvation.

There were no statistically significant $(P>0.05)$ effects of diet on the plasma FFA levels of fed birds (killed at $28 \mathrm{~d}$ of age). Fasting resulted in a considerable increase in FFA levels in birds previously given diet I. Fasting had no statistically significant effect on levels in birds previously given other biotin-deficient diets, but caused a reduction of levels in birds given diets 4,6 and 8 .

Hyperlipidaemia was not found in any group.

Tissue fatty acid composition. The amounts of $\mathrm{C}_{16}$ and $\mathrm{C}_{18}$ component fatty acids in adipose tissue of fed birds are given in Table 5. Birds given diet I had a higher proportion of $16: 1$ fatty acids and less 18 :0 than did those given diet 2. Addition of fat or protein to the diet considerably altered adipose tissue fatty acid composition but the biotin level of these other diets had no effect. The adipose tissue fatty acid compositions of fasted birds were also determined but these were not found to differ from those of fed birds given the same dietary treatment. The occurrence of FLKS among fed or fasted birds did not affect adipose fatty acid composition.

Liver fatty acid compositions are given in Table 6 . The only significant $(P<0.05)$ effects of biotin deficiency occurred with the low-fat, low-protein diet (diet 1 ) where there was an increase in the proportion of $16: 1$ fatty acids and a decrease in that of I8: 0 fatty acids compared with birds given diet 2 . 
Table 6. Fatty acid composition of liver at $28 \mathrm{~d}$ of age or after fasting for a further $\mathrm{I} 8 \mathrm{~h}$ in chicks given biotin-deficient or biotin-supplemented diets with high or low protein and fat contents

(Mean values with their standard errors for five to ten birds/treatment)

\begin{tabular}{|c|c|c|c|c|c|c|c|c|c|c|c|}
\hline \multirow[b]{3}{*}{ Diet* } & \multirow[b]{3}{*}{ 'Type of bird } & \multicolumn{10}{|c|}{ Component fatty acids $(\mathrm{mg} / \mathrm{g})$} \\
\hline & & \multicolumn{2}{|c|}{$16: 0$} & \multicolumn{2}{|c|}{ I6:I } & \multicolumn{2}{|c|}{ 18:0 } & \multicolumn{2}{|c|}{ I $8: I$} & \multicolumn{2}{|c|}{ I $8: 2$} \\
\hline & & Mean & $\mathrm{SE}$ & Mean & SE & Mean & $\mathrm{SE}$ & Mean & $\mathrm{SE}$ & Mean & $S E$ \\
\hline $\begin{array}{l}\text { Biotin-deficient } \\
\text { I (low-protein, low-fat) }\end{array}$ & $\begin{array}{l}\text { Fed } \\
\text { Fed (FLKS) } \\
\text { Fasted (FLKS) }\end{array}$ & $\begin{array}{l}309 \\
276 \\
255\end{array}$ & $\begin{array}{r}\text { II } \cdot 4 \\
6 \cdot 7 \\
7 \cdot 6\end{array}$ & $\begin{array}{l}163 \\
234 \\
209\end{array}$ & $\begin{array}{r}12 \cdot 7 \\
5 \cdot 9 \\
12 \cdot 4\end{array}$ & $\begin{array}{l}65 \\
29 \\
32\end{array}$ & $\begin{array}{l}7 \cdot 0 \\
3 \cdot 8 \\
3 \cdot 7\end{array}$ & $\begin{array}{l}379 \\
402 \\
417\end{array}$ & $\begin{array}{l}12 \cdot 1 \\
11 \cdot 1 \\
11 \cdot 2\end{array}$ & $\begin{array}{l}84 \\
59 \\
85\end{array}$ & $\begin{array}{l}7 \cdot 0 \\
6 \cdot 7 \\
6 \cdot 5\end{array}$ \\
\hline 3 (low-protein, high-fat) & $\begin{array}{l}\text { Fed } \\
\text { Fasted }\end{array}$ & $\begin{array}{l}199 \\
207\end{array}$ & $\begin{array}{l}9 \cdot 6 \\
9 \cdot 1\end{array}$ & $\begin{array}{l}4 \\
5\end{array}$ & $\begin{array}{l}I \cdot 2 \\
I \cdot I\end{array}$ & $\begin{array}{l}284 \\
298\end{array}$ & $\begin{array}{l}8 \cdot 5 \\
8 \cdot 1\end{array}$ & & $\begin{array}{r}6 \cdot 2 \\
12 \cdot 2\end{array}$ & $\begin{array}{l}391 \\
383\end{array}$ & $\begin{array}{r}9.4 \\
12 \cdot 6\end{array}$ \\
\hline 5 (high-protein, low-fat) & $\begin{array}{l}\text { Fed } \\
\text { Fed (FLKS)† } \\
\text { Fasted } \\
\text { Fasted (FLKS) } \dagger\end{array}$ & $\begin{array}{l}278 \\
245 \\
280 \\
246\end{array}$ & $\frac{3.8}{7^{\cdot 2}}$ & $\begin{array}{r}76 \\
233 \\
49 \\
210\end{array}$ & $\begin{array}{l}9 \cdot 1 \\
- \\
10 \cdot 4 \\
-\end{array}$ & $\begin{array}{r}186 \\
31 \\
211 \\
30\end{array}$ & $\begin{array}{l}17 \cdot 5 \\
24 \cdot 7 \\
-\end{array}$ & $\begin{array}{l}368 \\
408 \\
300 \\
441\end{array}$ & $\begin{array}{l}1 \times \cdot 7 \\
-14 \cdot 8\end{array}$ & $\begin{array}{r}96 \\
84 \\
\times 67 \\
73\end{array}$ & $\begin{array}{l}12 \cdot 3 \\
10 \cdot 1 \\
-\end{array}$ \\
\hline 7 (high-protein, high-fat) & $\begin{array}{l}\text { Fed } \\
\text { Fasted }\end{array}$ & $\begin{array}{l}221 \\
212\end{array}$ & $\begin{array}{r}\mathrm{II} \cdot 2 \\
8 \cdot 8\end{array}$ & $\begin{array}{l}5 \\
3\end{array}$ & $\begin{array}{l}I \cdot 8 \\
I \cdot 8\end{array}$ & $\begin{array}{l}292 \\
332\end{array}$ & $\begin{array}{l}7 \cdot 4 \\
7 \cdot 0\end{array}$ & $\begin{array}{r}137 \\
96\end{array}$ & $\begin{array}{l}8 \cdot 8 \\
2 \cdot 8\end{array}$ & $\begin{array}{l}346 \\
356\end{array}$ & $\begin{array}{l}15 \cdot 3 \\
12 \cdot 7\end{array}$ \\
\hline $\begin{array}{l}\text { Biotin-supplemented } \\
2 \text { (low-protein, low-fat) }\end{array}$ & $\begin{array}{l}\text { Fed } \\
\text { Fasted }\end{array}$ & $\begin{array}{l}297 \\
280\end{array}$ & $\begin{array}{r}14 \cdot 6 \\
3 \cdot 5\end{array}$ & $\begin{array}{l}56 \\
29\end{array}$ & $\begin{array}{l}6 \cdot 5 \\
5 \cdot 3\end{array}$ & $\begin{array}{l}171 \\
256\end{array}$ & $\begin{array}{r}15 \cdot 5 \\
8 \cdot 5\end{array}$ & $\begin{array}{l}397 \\
284\end{array}$ & $\begin{array}{l}18 \cdot 1 \\
15 \cdot 6\end{array}$ & $\begin{array}{r}80 \\
\times 51\end{array}$ & $\begin{array}{r}12 \cdot 1 \\
9 \cdot 8\end{array}$ \\
\hline 4 (low-protein, high-fat) & $\begin{array}{l}\text { Fed } \\
\text { Fasted }\end{array}$ & $\begin{array}{l}216 \\
245\end{array}$ & $\begin{array}{l}9 \cdot 0 \\
9 \cdot 1\end{array}$ & $\begin{array}{r}\text { I I } \\
7\end{array}$ & $\begin{array}{l}2 \cdot 2 \\
2 \cdot 1\end{array}$ & $\begin{array}{l}239 \\
309\end{array}$ & $\begin{array}{r}9 \cdot 5 \\
10 \cdot 1\end{array}$ & $\begin{array}{r}\text { I } 43 \\
97\end{array}$ & $\begin{array}{l}11 \cdot 5 \\
10 \cdot 7\end{array}$ & $\begin{array}{l}387 \\
344\end{array}$ & $\begin{array}{l}9 \cdot 8 \\
7 \cdot 5\end{array}$ \\
\hline 6 (high-protein, low-fat) & $\begin{array}{l}\text { Fed } \\
\text { Fasted }\end{array}$ & $\begin{array}{l}296 \\
256\end{array}$ & $\begin{array}{r}13 \cdot 4 \\
4 \cdot 0\end{array}$ & $\begin{array}{l}60 \\
22\end{array}$ & $\begin{array}{l}5 \cdot 4 \\
2 \cdot 6\end{array}$ & $\begin{array}{l}180 \\
286\end{array}$ & $\begin{array}{r}10.8 \\
9.7\end{array}$ & $\begin{array}{l}399 \\
261\end{array}$ & $\begin{array}{r}15 \cdot 1 \\
9 \cdot 3\end{array}$ & $\begin{array}{r}65 \\
174\end{array}$ & $\begin{array}{l}5 \cdot 3 \\
6 \cdot 9\end{array}$ \\
\hline 8 (high-protein, high-fat) & $\begin{array}{l}\text { Fed } \\
\text { Fasted }\end{array}$ & $\begin{array}{l}23^{8} \\
213\end{array}$ & $\begin{array}{l}8 \cdot 1 \\
7 \cdot 0\end{array}$ & $\begin{array}{l}5 \\
5\end{array}$ & $\begin{array}{l}1 \cdot 3 \\
0 \cdot 4\end{array}$ & $\begin{array}{l}287 \\
315\end{array}$ & $\begin{array}{l}24.5 \\
10.4\end{array}$ & $\begin{array}{l}\text { I } 22 \\
\text { I } 13\end{array}$ & $\begin{array}{l}9 \cdot 1 \\
8 \cdot 4\end{array}$ & $\begin{array}{l}348 \\
354\end{array}$ & $\begin{array}{l}\text { I } 2 \cdot 8 \\
\text { II } 3\end{array}$ \\
\hline
\end{tabular}

FLKS, fatty liver and kidney syndrome; fed, birds not showing histological changes of FLKS when killed at $28 \mathrm{~d}$ of age; fed (FLKS), birds dead from or showing severe histological changes of FLKS at autopsy; fasted, birds not showing histological changes of FLKS after $18 \mathrm{~h}$ fast; fasted (FLKS), birds showing severe histological changes of FLKS after $18 \mathrm{~h}$ fast.

* For details of diets, see Table 1 and p. I 6 .

$\uparrow$ Values for one bird.

Liver fatty acid compositions of birds given diets $I$ and 5 which died from spontaneous FLKS were similar and indicated the characteristic changes of the syndrome, i.e. increases in the proportions of the monounsaturated fatty acids at the expense of saturated fatty acids. Similar changes were found with these diets in birds which developed severe FLKS during the period of starvation. All fasted birds previously given diet I had changes typical of FLKS. However, with all other diets, fasting caused characteristic changes in the liver fatty acid compositions of birds which did not show signs of FLKS. These changes were mainly increases in the proportions of $18: 0$ fatty acids and decreases in those of $18: 1$ fatty acids, but with diets 2,5 and 6 there were also decreases in the proportions of $16: 1$ fatty acids and increases in the proportions of $18: 2$ fatty acids in fasted birds. 


\section{Expt 2}

Of the fifteen birds used in this experiment, fourteen (93\%) had died from FLKS by 5 weeks of age. The remaining bird survived until the end of the experiment at 8 weeks of age, when it was killed.

\section{DISCUSSION}

In these experiments both the severity of biotin deficiency and the occurrence of FLKS were affected by nutritional factors other than the biotin level of the diets. The biotin-deficient diets all contained the same amount of biotin $(0.015 \mathrm{mg} / \mathrm{kg})$, which was one-tenth of the requirement estimated by Anderson \& Warnick (1970) and all birds given these diets developed the typical signs of biotin deficiency (Scott et al. 1969). However, the severity of the signs, using retardation of growth and severity of dermal lesions as criteria, was affected by both the fat and protein levels of the diets. By both criteria, biotin deficiency was least severe with the low-fat, lowprotein diet and addition of either fat or protein to the diet increased the severity of the deficiency. The deficiency signs were most severe when the diet contained both high fat and high protein levels. Roland \& Edwards (197I) have reported that unsaturated fat can increase the severity of biotin deficiency but the similar effect of protein does not appear to have been reported previously.

Tissue lipid composition was affected by biotin deficiency only with the low-fat, low-protein diet. In both adipose tissue and liver lipids there was an increase in the ratio, palmitoleic acid:stearic acid. Similar changes have been found previously with biotin-deficient, fat-free or low-fat diets (Roland \& Edwards, 1971) and it has been suggested that the palmitoleic acid:stearic acid ratio might be used to assess biotin status in the chick (Edwards, Denman \& Jackson, 1973). However, these changes do not occur in biotin deficiency when the diet contains high fat or protein levels.

The FLKS that developed in birds given the purified diets used in these experiments was identical to that previously described in birds given practical diets. There were fatty infiltrations in liver, kidney, heart and other tissues (Wight \& Siller, 1975), reduced blood glucose and increased blood FFA levels (Bannister et al. 1975 $a$; Evans et al. 1975) and characteristic changes in liver fatty acid composition (Whitehead, 1975). Also, the syndrome was associated with the same responses to diet that had been found in field trials, because its incidence could be reduced by increasing fat or protein levels (Whitehead \& Blair, I974a; Blair et al. 1975) and eliminated by increasing the biotin level (Payne et al. 1974; Whitehead \& Blair, 1974b). With practical diets containing $\mathrm{I} 80 \mathrm{~g} \mathrm{CP}, \mathrm{I} 8 \mathrm{~g}$ diethyl ether extract and about $0.06 \mathrm{mg}$ available biotin $/ \mathrm{kg}$, mortality in a series of experiments averaged about $25 \%$ up to 8 weeks of age (Blair et al. 1975; Whitehead, Blair, Bannister \& Evans, I975; Whitehead, Blair, Bannister, Evans \& Jones, 1975). In the present experiment a purified diet with similar protein and fat levels ( $180 \mathrm{~g} \mathrm{CP}$, Io $\mathrm{g}$ diethyl ether extract $/ \mathrm{kg}$ ) but lower biotin content $(0.015 \mathrm{mg} / \mathrm{kg})$ caused $93 \%$ mortality from FLKS in the same period.

Fasting was an effective means of inducing FLKS, although the possibility could 
not be excluded that in some instances spontaneous FLKS had started before the fasting period, since the histological and biochemical changes found in starvationinduced FLKS resembled in every respect those of the spontaneous syndrome. Fasting was most effective in inducing FLKS with diets that were already causing the syndrome. Thus every bird that had been given the low-protein, low-fat diet (diet I) was either dead from or showed signs of the syndrome $18 \mathrm{~h}$ after food had been withdrawn. In contrast, only one bird given the low-protein, high-fat diet (diet 3) was showing mild histological signs, and none of the birds given the high-protein, high-fat diet (diet 7) showed any signs of FLKS after fasting.

Fasting had marked effects on liver fatty acid composition. When FLKS did not occur, the principal change in birds given each diet was an increase in the proportion of $18: 0$ fatty acids at the expense of the monounsaturated fatty acids. This change was the exact opposite of that which occurred when a bird developed FLKS. 'There is thus no evidence that fasting initiates FLKS by its effect on fatty acid metabolism.

Fasting resulted in a marked increase in plasma FFA levels only in birds which had developed FLKS. However, the levels were unexpectedly high in all fed birds (killed at $28 \mathrm{~d}$ of age) and, although there was no explanation for this, it would account for the absence of increased levels after fasting, with diets other than diet $I$.

Plasma glucose levels were reduced in all birds showing signs of FLKS and also in fasted birds previously given diets 2, 3, 4 and 5 not affected by the syndrome. Reduced glucose concentration is a normal effect of fasting, but the magnitude of the decrease appeared to be related to the dietary factors associated with FLKS. In particular, there was a large decrease in blood glucose levels in birds given the low-protein, low-fat diet (diet 2). This response may be explained by the relative paucity of dietary glucogenic amino acids and glycerol from triglyceride; the low levels of hepatic glycogen in birds of this age (Bannister et al. 1975a) may also contribute to the effect. The importance of the gluconeogenic pathway in the normal metabolism of the young chick is not well understood, although it is known that the activities of certain gluconeogenic enzymes decrease after hatching (Pearce $\&$ Brown, I97I). It is possible therefore that when low-fat, low-protein diets are fed gluconeogenesis is reduced further.

Biotin is also a cofactor in the lipogenic pathway, and both low dietary protein and low dietary fat levels are known to result in increased rates of hepatic lipogenesis (Yeh \& Leveille, I969; Yeh, Leveille \& Wiley, r970). Therefore, in birds given a low-fat, low-protein, high-carbohydrate diet of limited biotin content, most of the biotin may be bound to the acetyl-CoA carboxylase $(E C$ 6.4.I.2; acetyl-CoA: carbon-dioxide ligase (ADP)) involved in lipogenesis with little free biotin available for pyruvate carboxylase. Therefore a period of prolonged fasting might induce acute hypoglycaemia and resultant FLKS in birds previously given this diet. In contrast the results suggest that gluconeogenesis is not impaired in birds given high-fat or high-protein diets even in the presence of very low biotin levels and this may be due to the availability of glucogenic amino acids and glycerol, which by-pass pyruvate carboxylase.

This proposed mechanism for the induction of FLKS by fasting may not account 
for the occurrence of spontaneous FLKS as there is no evidence that, in the latter, birds have experienced prolonged fasting or that their digestion of carbohydrate is impaired (Bannister, Evans \& Whitehead, 1975 $b$ ). Nor does it suggest that FLKS is a biotin-deficiency condition alone. However, if FLKS is a direct result of biotin deficiency, then this is an unusual situation in which, depending on the fat or protein content of the diet, a deficiency of biotin may result in either severe dermal lesions or less severe dermal lesions but possible death from FLKS.

The authors thank Mr I. Fender for assistance with the fatty acid analyses and F. Hoffmann-La Roche \& Co., Basle, for biotin assay of the diets.

\section{REFERENCES}

Anderson, J. O. \& Warnick, R. E. (1970). Poult. Sci. 49, 569.

Bannister, D. W. (1975). Comp. Biochem. Physiol. 52B (In the Press.)

Bannister, D. W., Evans, A. J. \& Whitehead, C. C. (1975a). Res. vet. Sci. r8, I49.

Bannister, D. W., Evans, A. J. \& Whitehead, C. C. (1975b). Res. vet. Sci. 19, 90.

Blair, R., Whitehead, C. C. \& Teague, P. W. (1975). Res. vet. Sci. 18, 76.

Edwards, H. M., Denman, F. \& Jackson, R. (r973). Poult. Sci. 52, 2024.

Evans, A. J., Bannister, D. W. \& Whitehead, C. C. (1975). Res. vet. Sci. 18, 26.

Folch, J., Lees, N. \& Sloane Stanley, G. H. (I957). F. biol. Chem. 226, 497.

Hemsley, L. A. (1973). Vet. Rec. 93, 256.

Morley, G., Dawson, A. \& Marks, V. (1968). Proc. Ass. clin. Biochem. 5, 42.

Payne, C. G., Gilchrist, P., Pearson, J. A. \& Hemsley, L. A. (1974). Br. Poult. Sci. r5, 489.

Pearce, J. \& Brown, W. O. (r97r). In Physiology and Biochemistry of the Domestic Fozvl, vol. 1, p. 295

[D. J. Bell and B. M. Freeman, editors]. London: Academic Press.

Roland, D. A. \& Edwards, H. M. (197r). F. Nutr. Ior, 81 I.

Scott, M. L., Nesheim, M. C. \& Young, R. J. (1969). Nutrition of the Chicken. Ithaca, New York: M. L. Scott and Associates.

Whitehead, C. C. (1975). Res. vet. Sci. 18, 32.

Whitehead, C. C., Bannister, D. W., Wight, P. A. L. \& Weiser, H. (I974). Proc. xvth Wld Poult. Congr. p. 70 .

Whitehead, C. C. \& Blair, R. (1974a). Res. vet. Sci. x7, 86.

Whitehead, C. C. \& Blair, R. (I 974b). Wld's Poult. Sci. J. 30, 23 т.

Whitehead, C. C., Blair, R., Bannister, D. W. \& Evans, A. J. (1975). Res, vet. Sci. r8, roo.

Whitehead, C. C., Blair, R., Bannister, D. W., Evans, A. J.\& Jones, R. M. (r975). Res. vet. Sci. Ig (In the Press.)

Wight, P. A. L. \& Siller, W. G. (r975). Res. vet. Sci. r9, I73.

Wright, L. D. \& Skeggs, H. R. (1944). Proc. Soc. exp. Biol. Med. 56, 95.

Yeh, Y.-Y. \& Leveille, G. A. (1969). F. Nutr. 98, 356.

Yeh, Y.-Y., Leveille, G. A. \& Wiley, J. H. (1970). F. Nutr. 1oo, 917. 